DOI: $10.29303 /$ jrpb.v8i1.161

ISSN 2301-8119, e-ISSN 2443-1354

Tersedia online di http://jrpb.unram.ac.id/

\title{
UJI KINERJA SISTEM KONTROL UNTUK PENGENDALIAN SUHU PADA ALAT PENGERING BIJI-BIJIAN BERBASIS FUZZY LOGIC
}

\author{
Performance Test of Control Systems for Temperature Control in Seeds Dryer \\ based on Fuzzy Logic \\ Dwi Santoso $^{1, *}$, Abdul Waris ${ }^{2}$ \\ ${ }^{1}$ Jurusan Agroteknologi, Fakultas Pertanian, Universitas Borneo Tarakan \\ Jl. Amal Lama No.1, Tarakan 77126, Indonesia \\ ${ }^{2}$ Departemen Teknologi Pertanian, Fakultas Pertanian, Universitas Hasanuddin \\ J1. Perintis Kemerdekaan Km.10, Makassar 90245, Indonesia \\ Email $^{*}$ : dwiborneo11@gmail.com \\ Diterima: Desember 2019 \\ Disetujui: Februari 2020
}

\begin{abstract}
The dryer of agricultural products is more appropriate if designed based on fuzzy logic and expert system. To show the development results, then the control system of fuzzy logic is set on the batch dryer of agricultural products. This study aimed to produce prototype the batch Agricultural product dryer using fuzzy logic system control and to find out the implementation of fuzzy logic and in the dryer body types. This study employed a Hybrid method (fuzzy and crisp sets) to design control rules of fuzzy logic in converting the control signal to be a signal that can be used to move the mechanical actuator. The results showed that the application of the fuzzy logic control system in the dryer machine type batch showed better performance, did not occur overshoot and was able to save the use of LPG gas energy during the drying process. The amount of power used by the control system during the testing process is 304,760 (Watt.hours).
\end{abstract}

Keywords: fuzzy logic, microcontroller, drying

\begin{abstract}
ABSTRAK
Mesin pengering hasil pertanian akan baik jika dirancang berbasiskan logika fuzzy untuk menunjukkan hasil pengembangan maka sistem kontrol fuzzy logic diterapkan pada mesin pengering hasil pertanian tipe batch. Penelitian ini bertujuan menghasilkan prototype alat pengering hasil pertanian menggunakan sistem kontrol fuzzy logic dan mengetahui cara penerapan fuzzy logic pada alat pengering tipe batch. Penelitian ini menerapkan metode hybrid (himpunan fuzzy dan crisp untuk mendesain kaidah-kaidah logika fuzzy kemudian mengonversi sinyal kontrol menjadi sinyal yang dapat digunakan untuk menggerakkan aktuator mesin. Hasil penelitian menunjukkan bahwa penerapan sistem kontrol fuzzy logic pada alat pengering bijibijian tipe batch menunjukkan kinerja lebih baik, tidak terjadi overshoot, dan mampu menghemat penggunaan energi gas LPG selama proses pengeringan. Jumlah daya yang digunakan sistem kontrol selama proses pengujian dilakukan, yaitu 304.760 (Watt.jam).
\end{abstract}


Kata kunci: fuzzy logic, mikrokontroler, pengeringan

\section{PENDAHULUAN}

\section{Latar Belakang}

Mesin pengering hasil pertanian saat ini lebih banyak menggunakan gas LPG sebagai tenaga pemanas karena lebih efisien, murah dan praktis dalam penggunaannya. Namun, gas LPG sulit dikendalikan dengan sistem kontrol biasa karena dapat membuat fluktuasi suhu yang besar (Soemarsono, dkk., 2016). Berdasarkan Argo \& Rahayu (2012) salah satu cara untuk mendapatkan hasil pengeringan bahan yang baik adalah dengan membuat alat pengering terkendali. Oleh karena itu, dibutuhkan suatu sistem cerdas yang mampu mengendalikan suhu pada tungku pengering sehingga suhu ruang pengering diharapkan tidak akan mengalami fluktuasi. Bahan yang dikeringkan tidak akan mengalami kerusakan karena bahan menerima suhu yang sesuai untuk pengeringan bahan tersebut (Hasibuan, 2004). Selain itu, penggunaan sistem kendali suhu pada pengering adalah untuk penghematan penggunaan energi karena besarnya energi yang diberikan ke pemanas diatur oleh sistem kendali cerdas sesuai dengan suhu yang digunakan untuk pengeringan (Chbat \& Badami, 2000).

Saat ini teknologi fuzzy logic telah banyak digunakan pada berbagai mesin dan alat elektronik. Penerapan sistem kecerdasan buatan berdasarkan (Nasution, 2012), yaitu seperti mesin elektronik berbasis fuzzy logic, pemanas dan pendingin ruangan.

Mengacu pada permasalahan untuk membuat alat pengering terkendali yang sejalan dengan perkembangan teknologi, (Dufour, 2006) menjelaskan bahwa perlunya pengembangan mengenai sistem pengendalian suhu udara pada alat pengering produk pertanian dengan sistem kontrol fuzzy logic. Dengan demikian dibutuhkan suatu rancangan untuk mempelajari cara penerapan fuzzy logic pada alat pengering biji-bijian.

\section{Tujuan}

Tujuan penelitian ini adalah merancang prototype alat pengering yang menggunakan fuzzy logic dan untuk mempelajari cara penerapan fuzzy logic pada alat pengering biji-bijian.

\section{METODE PENELITIAN}

\section{Deskripsi Alat Pengering Biji-Bijian}

Alat pengering hasil desain ini terdiri dari tungku dan kotak pengering, tungku terdiri atas ruang pembakaran, ruang penukar panas, kompor dan blower. Sedangkan pada kotak pengering terdiri atas ruang pengeringan dan ruang plenum. Alat pengering ini dikendalikan oleh mikrokontroler yang telah terprogram.

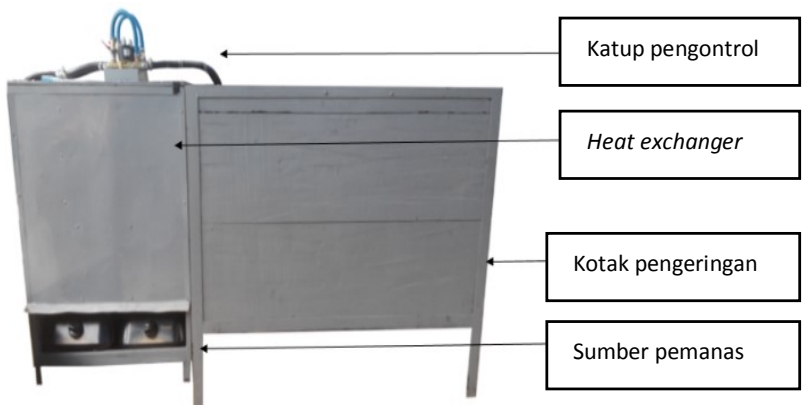

Gambar 1. Alat pengering biji-bijian berbasis logika fuzzy

Spesifikasi:

1. Dimensi tungku: $54 \mathrm{~cm} \mathrm{x} 40 \mathrm{~cm} \times 66$ $\mathrm{cm}$

2. Dimensi kotak pengering: $90 \mathrm{~m} \times 60 \mathrm{~cm} \times 54 \mathrm{~cm}$

3. Kapasitas pengeringan: $40 \mathrm{~kg}$

4. Dinding Tungku terbuat dari plat alumunium $1 \mathrm{~mm}$ dan $0,7 \mathrm{~mm}$

5. sumber pemanas: Kompor gas dengan total energi 3600 Watt

6. Blower berukuran 3 inch

7. Sumber energi: gas LPG

\section{Rancangan Penelitian}

Merancang Sistem Alat Pengering berbasis Fuzzy logic

Kegiatan pertama yang dilakukan pada penelitian ini, yaitu merancang sistem alat pengering. Alat pengering biji-bijian 
terdiri dari beberapa bagian utama yaitu ruang plenum, ruang pengeringan dan tungku (Murdianto \& Santoso, 2019). Tungku terdiri dari ruang bakar, blower dan plat pembatas. Sistem alat pengering bijibijian dapat dilihat pada Gambar 2 .

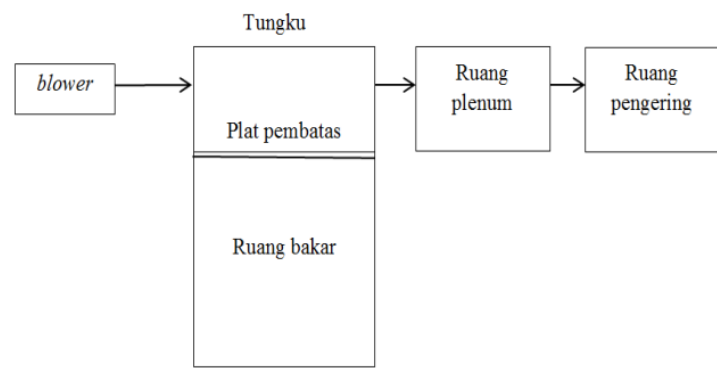

Gambar 2. Sistem Alat Pengering

Untuk mengendalikan suhu di ruang pengering, pada ruang bakar terdapat dua kompor berbahan bakar gas LPG. Setiap kompor dihubungkan oleh solenoid valve, dimana solenoid valve berfungsi sebagai pengatur laju pembakaran gas. Solenoid dihubungkan ke mikrokontroler yang telah diberi program fuzzy yang berfungi sebagai perintah untuk mengatur bukaan katup pada aktuator. Perancangan alat pengering harus memenuhi beberapa syarat untuk mendapatkan model yang baik dan efisien, diantaranya kebutuhan udara pengeringan dan kebutuhan energi pengeringan (Dufour, 2006).

Kebutuhan Udara Pengeringan

Untuk mengetahui ukuran blower yang tepat untuk tungku, dilakukan penghitungan kebutuhan udara pengering menggunakan grafik psychrometric (Adriansyah, 2017). Pada penelitian ini, kebutuhan udara pengering untuk alat pengering biji-bijian kapasitas $40 \mathrm{~kg}$ yaitu $0,055 \mathrm{~m}^{3} /$ detik. Oleh karena itu, dipilih blower 3 inch dengan kecepatan udara $0,055 \mathrm{~m}^{3} /$ detik karena sesuai dengan kebutuhan udara pengeringan.

\section{Kebutuhan Energi Pengeringan}

Kebutuhan energi pengeringan adalah jumlah energi atau daya yang dibutuhkan di dalam tungku pemanas (Santoso, dkk., 2018). Daya yang diperlukan untuk alat pengering kapasitas $40 \mathrm{~kg}$ dengan kadar air awal $60 \%$ agar mencapai kadar air 10\% adalah 1800 Watt. Untuk mencapai kondisi efisiensi termal, maka daya 1800 Watt perlu ditambah. Oleh karena itu, dalam penelitian ini ditetapkan kebutuhan energi pengering sebesar 3200 watt.

\section{Merancang Hardware dan Software Sistem Kontrol}

Pada penelitian ini, setiap prosesnya terdiri dari satu input dan satu output. Input terbagi menjadi Error dan Delta Error. Berdasarkan sistem MISO (multi input single output), diperoleh hasil desain model sistem kontrol alat pengering seperti diperlihatkan pada Gambar 3.

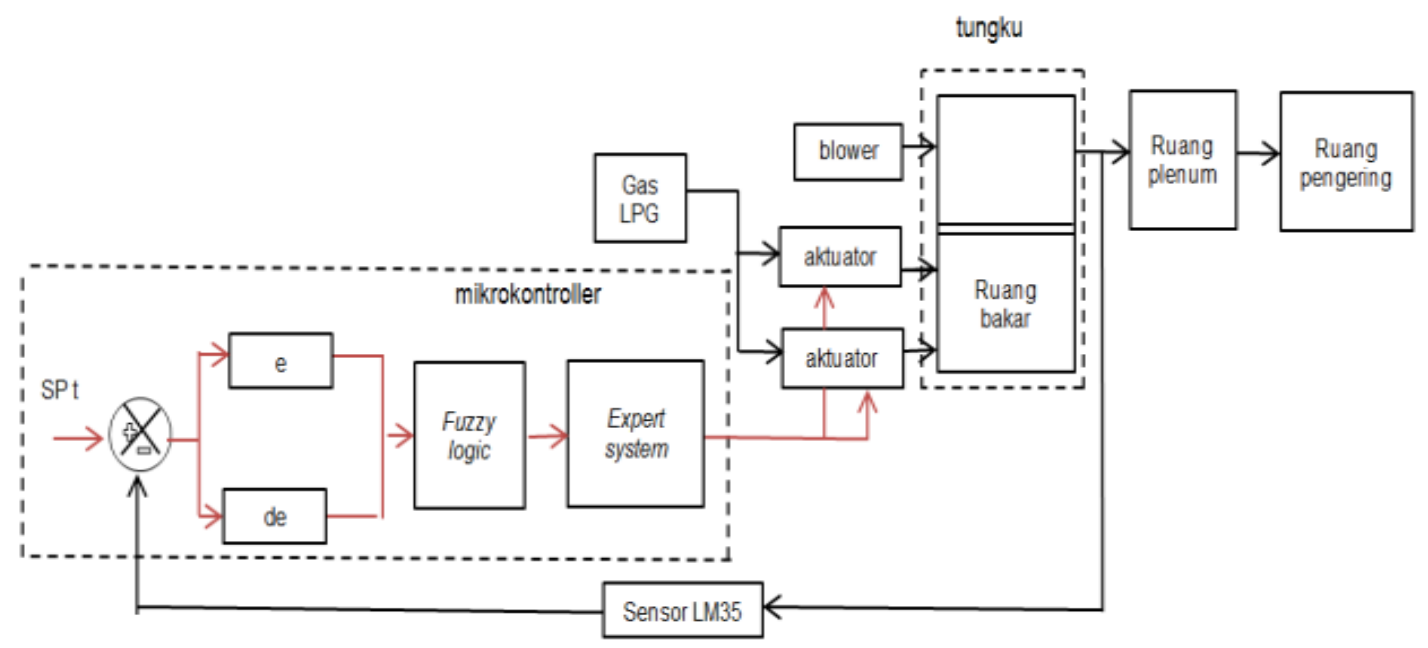

Gambar 3. Model Sistem Kontrol Proses Alat Pengering 
Berdasarkan Dewi \& Hartati (2010), Logika fuzzy merupakan salah satu penyelesaian masalah kontrol dengan pendekatan berbasis aturan, dan output yang dihasilkan adalah bilangan analog, kemudian bilangan analog tersebut diaplikasikan dalam bentuk nyata (real time).

\section{Simulasi Offline}

Simulasi offline, yaitu proses memetakan ruang input ke dalam ruang output sesuai dengan kaidah-kaidah fuzzy, simulasi menggunakan software Matlab (Kasabov \& Song, 2002). Jika nilai masukan sudah sesuai dengan nilai keluaran yang diinginkan, maka kaidah-kaidah fuzzy dianggap sudah benar. Namun, jika nilai simulasi belum sesuai dengan hasil yang diinginkan, maka kembali ke semesta pembicaraan untuk menentukan range yang sesuai.

\section{Penerapan Kontrol Logika Fuzzy}

Penerapan kontrol logika Fuzzy dilakukan oleh mikrokontroler ATMega 32 yang digunakan untuk proses pengeringan. Mikrokontroler dirangkai dengan catu daya, sensor suhu, display LCD, Relay dan Solenoid membentuk satu sistem kontrol alat pengering biji-bijian yang diinjeksikan atau di-upload ke dalam software logika Fuzzy. Apabila hasil analisis respon sistem belum sesuai yang diinginkan, maka dilakukan simulasi menggunakan Matlab untuk mencari kaidah mana yang belum bekerja. Hasil simulasi dijadikan dasar untuk tuning secara real-time (Naba, 2009). Pengujian alat terbagi atas dua bagian, yaitu uji fungsional dan uji kinerja.

\section{Uji Fungsional}

Dalam uji fungsional dilakukan pengujian kontrol tanpa bahan. Jika pengujian menunjukkan hasil yang baik, berarti komponen yang membangun alat pengering sudah berjalan sesuai fungsi masing-masing (Hasnan, 2017). Sebaliknya, jika hasil belum sesuai dengan yang diharapkan, maka dilakukan perbaikan.

\section{Uji Kinerja}

Pengujian kinerja kontrol bertujuan untuk mengetahui kinerja penerapan sistem kontrol selama proses pengeringan, parameter yang diamati meliputi suhu udara pengering, kestabilan terhadap gangguan, konsumsi daya serta penurunan kadar air. Tungku menggunakan dua kompor gas merek Rinnai dengan total daya yang dihasilkan, yaitu 3600 Watt, untuk memenuhi kebutuhan energi pengeringan sebesar 3200 Watt.

Besaran daya pada tungku (gain) mempengaruhi kinerja kontrol dan fisik dari bahan yang dikeringkan. Jika daya tungku terlalu besar maka akan memberikan respon yang terlalu cepat akibatnya suhu berlebih di awal proses (overshoot) dan cenderung tidak stabil serta bahan yang berupa biji-bijian dapat mengalami retak pada permukaannya. Namun, jika tungku terlalu kecil cenderung akan terjadi offset (suhu lebih kecil dari yang diharapkan) dan bahan seperti biji-bijian yang memiliki protein tinggi dapat berjamur karena proses pemanasan yang lambat.

\section{HASIL DAN PEMBAHASAN}

\section{Uji Kontrol Tanpa Bahan}

Gambar 4 menunjukkan respon suhu udara selama pengujian kontrol tanpa menggunakan bahan. Pengujian dilakukan selama kurang lebih 15 menit, grafik menunjukkan suhu mampu mencapai setting point pada suhu $60^{\circ} \mathrm{C}$ secara perlahan. Hal ini menunjukkan komponen di dalam alat pengering dapat bekerja dengan baik.

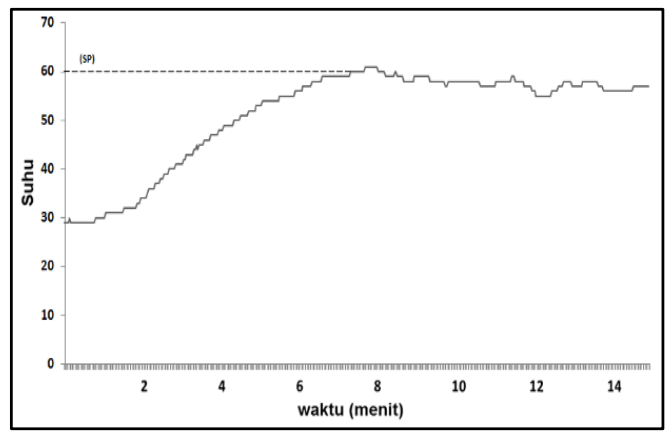

Gambar 4. Respon Suhu Udara pada Uji Tanpa Bahan 
Berdasarkan grafik diketahui bahwa waktu yang diperlukan untuk mencapai setting point adalah 8 menit. Hal ini menunjukkan bahwa gain alat pengering cukup besar, dengan kata lain daya yang digunakan cukup baik untuk melakukan proses pengeringan. Kenaikan suhu relatif cepat yaitu sebesar $3{ }^{\circ} \mathrm{C} /$ menit, kondisi seperti ini memperlihatkan seberapa baik kinerja sistem kontrol dalam mengatasi energi gain alat pengering yang cukup besar. Pada grafik nampak terjadi overshoot $1^{\circ} \mathrm{C}$ di atas setting point selama beberapa detik, kemudian suhu perlahan kembali turun. Hal ini menunjukkan bahwa sistem kontrol sudah bekerja sesuai dengan kaidah-kaidah fuzzy yang diberikan.

Grafik tersebut menunjukkan terjadinya osilasi suhu selama pengujian, setelah mencapai setting point suhu perlahan-lahan mengalami osilasi atau penurunan suhu hingga mencapai $2{ }^{\circ} \mathrm{C}$ di bawah setting point. Hal ini disebabkan karena ruang plenum tidak tertutupi oleh tumpukan bahan, yang mengakibatkan suhu langsung keluar ke lingkungan (Kakomole, 2012). Harsono, dkk., (2011), juga menjelaskan bahwa tidak adanya bahan yang dikeringkan membuat udara panas yang masuk ke ruang plenum tidak terakumulasi, sehingga suhu sulit untuk naik.

\section{Analisis Suhu Udara Pengering}

Analisis suhu udara pengering dilakukan untuk mengetahui tingkat ketelitian sistem kontrol selama proses pengeringan. Gambar 5 menunjukkan hasil pengamatan suhu udara pengering selama pengujian kontrol. Variabel yang diamati yaitu proses perubahan suhu terhadap lama pengeringan. Pada gambar terlihat bahwa respon suhu sistem kontrol cukup stabil dengan waktu menetap (setling time) yang relatif kecil.

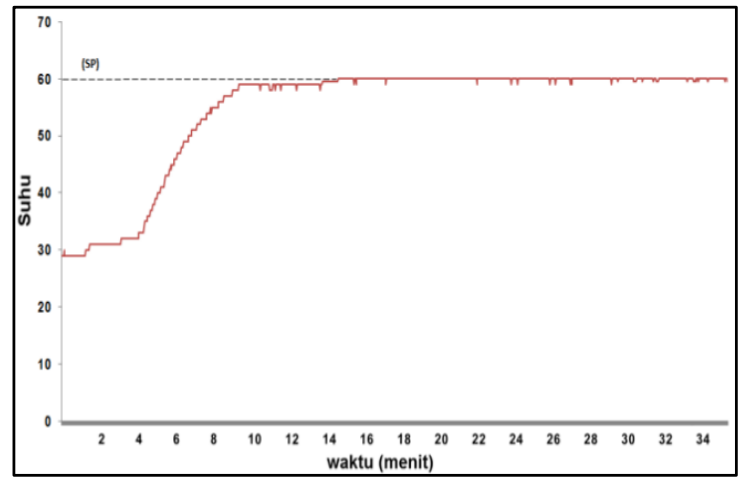

Gambar 5. Respon Suhu Udara Pada Kontrol Logika Fuzzy

Terdapat dua kondisi pada kontrol expert, yaitu daya tinggi (3600 Watt) dan daya kecil (1400 Watt); jika suhu di bawah titik atur (Setting Point), maka kontrol akan memakai daya tinggi (3600 Watt) dan jika suhu mendekati titik atur (Setting Point), maka kontrol akan memakai daya kecil (1400 Watt).

Kontrol logika Fuzzy membutuhkan waktu 14 menit untuk mencapai titik atur (Setting Point), hal ini karena semakin mendekati titik atur maka kontrol merespon dengan memberikan daya sesuai perintah. Gambar 5 juga menunjukkan bahwa suhu berosilasi di bawah titik atur dan tidak terjadi overshoot, keadaan suhunya juga stabil dan kerja kontrol lebih halus. Kontrol logika fuzzy mampu memberikan respon lebih cepat karena bekerja ketika suhu turun $0,5^{\circ} \mathrm{C}$ di bawah titik atur. Sistem kerja logika fuzzy akan merespon lebih cepat terhadap segala interaksi dengan faktorfaktor lingkungan (Wang \& Wang, 1997).

\section{Kestabilan Terhadap Gangguan}

Gangguan yang dimaksud yaitu dengan cara mengaduk-aduk tumpukan biji kopi selama 10 menit dan mengamati respon masing-masing sistem kontrol selama gangguan dilakukan. Selama gangguan dilakukan, suhu yang telah terakumulasi di dalam ruang plenum cenderung turun karena udara panas yang telah terkumpul keluar ke lingkungan melalui celah pada saat pengadukan tumpukan biji. Penurunan suhu langsung direspon oleh sistem kontrol dengan memberikan daya sesuai kebutuhan, 
Kemampuan mereduksi gangguan yang baik dapat mengurangi konsumsi gas selama proses pengeringan berlangsung.

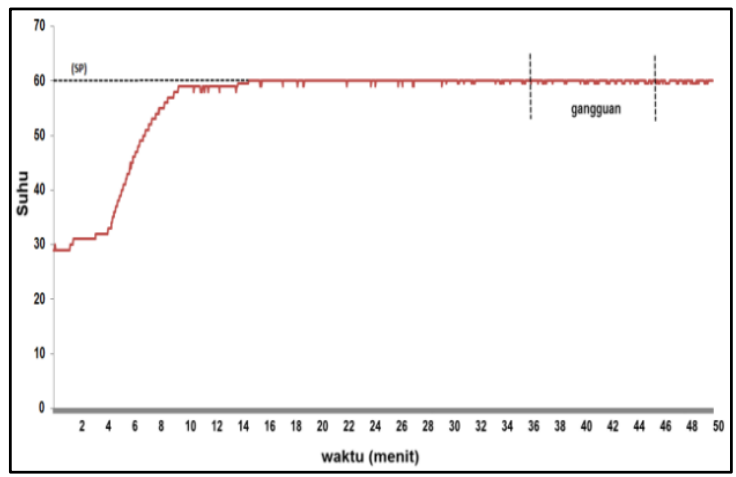

Gambar 6. Respon Kontrol Logika Fuzzy Terhadap Gangguan

Gambar 6 menunjukkan kemampuan kontrol logika fuzzy dalam merespon gangguan, pada grafik terlihat bahwa suhu stabil selama gangguan dilakukan, suhu berosilasi di bawah titik atur dan tidak terjadi overshoot. Hal ini karena kontrol logika fuzzy lebih cepat mengatasi gangguan, ketika suhu turun $0,5^{\circ} \mathrm{C}$ di bawah titik atur maka kontrol langsung merespon dengan memberikan daya yang sesuai kebutuhan (Wang \& Wang, 1997).

\section{Konsumsi Daya}

Penggunaan daya tergantung pada kondisi suhu, jika suhu yang terbaca oleh sensor di bawah suhu atur atau ketika terjadi gangguan, maka sistem kontrol akan menggunakan semua daya yang tersedia (Supriyono, dkk., 2015).

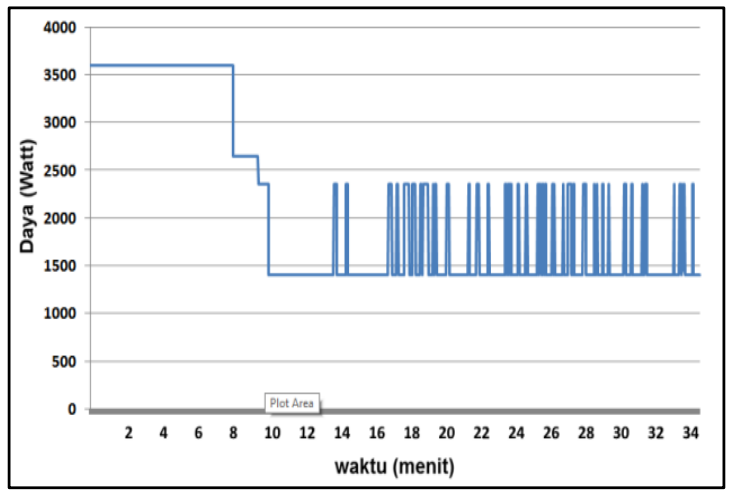

Gambar 7. Konsumsi Daya pada Kontrol Logika Fuzzy
Gambar 7 memperlihatkan pada awal pengeringan sistem kontrol, fuzzy logic menggunakan daya besar (3600 Watt) diberikan ketika suhu di bawah titik atur (setting point) dan daya kecil (1400 Watt) diberikan ketika suhu mulai mendekati titik atur (selisih $2^{\circ}$ ). Hal ini tentu membuat konsumsi daya lebih besar, namun kontrol logika fuzzy mampu mengurangi penggunaan daya ketika suhu mendekati suhu atur (setting point).

Saat suhu mulai mendekati titik atur, daya berangsur-angsur dikurangi sampai keadaan tunak tercapai. Daya turun menjadi 2650 Watt ketika suhu selisih $2^{\circ} \mathrm{C}$ dan turun lagi menjadi 2350 Watt ketika suhu selisih $1{ }^{\circ} \mathrm{C}$, ketika telah mencapai titik atur maka daya turun menjadi 1400 Watt. Hal ini yang menyebabkan suhu tidak overshoot dan tidak offset. Jumlah daya yang digunakan sistem kontrol selama proses pengujian dilakukan yaitu 304.760 (Watt.jam). Hal ini disebabkan kontrol logika fuzzy terdiri atas beberapa aturan atau kaidah fuzzy sehingga konsumsi daya diatur sesuai kebutuhan (Munir, 2011).

\section{KESIMPULAN}

Berdasarkan penelitian yang telah dilakukan pada alat pengering biji-bijian, dapat disimpulkan bahwa telah dihasilkan sistem kontrol fuzzy logic dan berhasil diterapkan pada alat pengering hasil pertanian tipe batch. Jumlah daya yang digunakan sistem kontrol selama proses pengujian dilakukan yaitu 304.760 (Watt.jam). Suhu yang stabil dan dapat menghemat penggunaan gas LPG menunjukkan bahwa sistem kontrol fuzzy logic dapat bekerja dengan baik.

\section{DAFTAR REFERENSI}

Adriansyah, M.G. (2017). Studi Eksperimen Pengaruh Variasi Kecepatan Dan Temperatur Udara Terhadap Kualitas Pengeringan Bagasse Pada Mesin Pengering Tipe Pneumatic/Flash 
Dryer. Institute Technology Sepuluh Nopember.

Argo, B.D., \& Rahayu, C. (2012). Model Simulasi Pengendalian Suhu Udara Pada Mesin Pengering Cabe Dengan Kontrol Logika Fuzzy. Jurnal Teknologi Pertanian, 5(3).

Chbat, N.W., \& Badami, V.V. (2000). Systems And Methods For Determining Drying Time For A Clothes Dryer: Google Patents.

Dewi, S., \& Hartati, S. (2010). Neuro-Fuzzy: Integrasi Sistem Fuzzy Dan Jaringan Syaraf, Edisi 2. Yogyakarta: Graha Ilmu.

Dufour, P. (2006). Control Engineering In Drying Technology: Review And Trends. Drying Technology, 24(7), 889-904.

Harsono, P. W., Budiharti, U., \& Mulyantara, F. T (2011). Pengujian Unit Pengering ERK-Hybrid Untuk Padi Kapasitas 5 Ton. Balai Besar Pengembangan Mekanisasi Pertanian.

Hasibuan, R. (2004). Mekanisme Pengeringan. Yogyakarta: Graha Ilmu.

Hasnan, M. (2017). Rancang Bangun Sistem Pengering Gabah Dengan Menggunakan Arduino. Skripsi. Universitas Islam Negeri Alauddin Makassar.

Kakomole, J.B. (2012). Karakteristik Pengeringan Biji Pala (Myristica Fragrans H) Menggunakan Alat Pengering Energi Surya Tipe Rak. Cocos, 1(1).

Kasabov, N.K., \& Song, Q. (2002). DENFIS: Dynamic Evolving NeuralFuzzy Inference System And Its
Application For Time-Series Prediction. IEEE Transactions on Fuzzy Systems, 10(2), 144-154.

Munir, R. (2011). Sistem Inferensi Fuzzy. Teknik Informatika-STEI ITB, Bandung.

Murdianto, D., \& Santoso, D. (2019). Pemodelan Mesin Pengering BijiBijian Tipe Batch Menggunakan Hybrid Petri Net. Jurnal Pertanian Berkelanjutan, 7(2), 115-120.

Naba, A. (2009). Belajar Cepat Fuzzy logic Menggunakan Matlab. Yogyakarta: Andi.

Nasution, H. (2012). Implementasi Logika Fuzzy Pada Sistem Kecerdasan Buatan. ELKHA, 4(2).

Santoso, D., Muhidong, D., \& Mursalim, M. (2018). Model Matematis Pengeringan Lapisan Tipis Biji Kopi Arabika (Coffeae arabica) dan Biji Kopi Robusta (Coffeae cannephora). Jurnal Teknologi Pertanian Andalas, 22(1), 86-95.

Soemarsono, B.E., Listiasri, E., \& Kusuma, G.C. (2016). Alat Pendeteksi Dini Terhadap Kebocoran Gas LPG. TELE, 13(1).

Supriyono, H., Ariwibowo, S., \& Irsyadi, F. Y.A. (2015). Rancang-Bangun Pengering Panili Otomatis Berbasis Mikrokontroler. Prosiding Simposium Nasional RAPI XIV - 2015 FT UMS, 50-56.

Wang, L.-X., \& Wang, L.-X. (1997). A Course In Fuzzy Systems And Control (Vol. 2): Prentice Hall PTR Upper Saddle River, NJ. 